

\section{NOTICE}

The submitted manuscript has been offered by an employee of the Alliance for Sustainable Energy, LLC (ASE), a contractor of the US Government under Contract No. DE-AC36-08-GO28308. Accordingly, the US Government and ASE retain a nonexclusive royalty-free license to publish or reproduce the published form of this contribution, or allow others to do so, for US Government purposes.

This report was prepared as an account of work sponsored by an agency of the United States government. Neither the United States government nor any agency thereof, nor any of their employees, makes any warranty, express or implied, or assumes any legal liability or responsibility for the accuracy, completeness, or usefulness of any information, apparatus, product, or process disclosed, or represents that its use would not infringe privately owned rights. Reference herein to any specific commercial product, process, or service by trade name, trademark, manufacturer, or otherwise does not necessarily constitute or imply its endorsement, recommendation, or favoring by the United States government or any agency thereof. The views and opinions of authors expressed herein do not necessarily state or reflect those of the United States government or any agency thereof.

Available electronically at http://www.osti.gov/bridge

Available for a processing fee to U.S. Department of Energy and its contractors, in paper, from:

U.S. Department of Energy

Office of Scientific and Technical Information

P.O. Box 62

Oak Ridge, TN 37831-0062

phone: 865.576.8401

fax: 865.576 .5728

email: mailto:reports@adonis.osti.gov

Available for sale to the public, in paper, from:

U.S. Department of Commerce

National Technical Information Service

5285 Port Royal Road

Springfield, VA 22161

phone: 800.553.6847

fax: 703.605.6900

email: orders@ntis.fedworld.gov

online ordering: http://www.ntis.gov/ordering.htm 


\title{
PERFORMANCE COMPARISON OF A BIPV ROOFING TILE SYSTEM IN TWO MOUNTING CONFIGURATIONS
}

\author{
Matthew Muller, Jose Rodriguez, Bill Marion \\ National Renewable Energy Laboratory (NREL), 1617 Cole Boulevard, Golden CO 80401, USA
}

\begin{abstract}
This paper examines the performance of a building integrated photovoltaic (BIPV) roofing system commonly available to residential markets. In particular polycrystalline Si PV roofing tiles were integrated with concrete roofing tiles in two mounting configurations being used by roofing contractors. In the first configuration the tiles were directly mounted to the roof sheeting allowing little to no airflow under the PV modules. In the second configuration furring strips were attached to the roof deck to create a counter-batten system to which the roofing and PV tiles mount. This counter-batten system provides an air gap between the roof deck and the PV/concrete tiles which allows for convective cooling. A complete data acquisition system was applied to both mounting configurations and they were monitored for a summer period in Golden, Colorado. A performance comparison is presented for the systems while both are gauged against freestanding rack-mounted polycrystalline Si PV modules. As expected, modules mounted directly to the deck operated at higher temperatures and produced less power than those on a counter-batten system while both systems operated at higher temperatures than rackmounted modules.
\end{abstract}

\section{INTRODUCTION}

As the photovoltaic industry has grown exponentially in recent years, various companies have successfully created separate product lines to serve as building integrated photovoltaics (BIPV). The basic premise is to combine the power generation of $\mathrm{PV}$ within common building materials such as roofing, glass, window shades, and other products. In attempts to provide an aesthetically pleasing roof, companies such as BP, GE, SunPower, Kyocera, Sharp, and Open Energy have all introduced PV tiles that integrate with standard concrete roofing tiles. Each of these brands has a slightly different appearance but each uses crystalline silicon PV cells built into modules which integrate with concrete roof tiles.

It is well known that with crystalline silicon PV, both voltage and power have a negative relationship with temperature [1]. For this reason mounting PV too close to a hot roof reduces power output and therefore elevating an array off the roof is desired. The PVFORM model [2] indicates that modules mounted 6" off the roof deck have an installed nominal operating cell temperature (INOCT) that is $2^{\circ} \mathrm{C}$ greater than modules mounted on an free-standing rack. NJATC [1] suggests that roof mounted arrays should be elevated 3 to 6 inches from the deck in order to optimize convective cooling, power output, and wind loading. Although it is documented that a BIPV roof system will produce less power than a similar PV module in and elevated array, the literature is sparse in actually attaching numbers to available BIPV products.

This study will not only quantify performance for one of the aforementioned PV roofing tile products but also will compare installation techniques used in the concrete roofing industry. It is common to find concrete roof tiles installed in one of three methods. In the first and least expensive method, the tiles are directly screwed to roof sheeting, termed direct-mount. In the second method, equally spaced horizontal running battens are attached to the roof deck and then the tiles are attached to these battens. In the third method, (called counter-batten system) vertical battens are first attached to the roof deck to elevate the horizontal battens and therefore the tiles. Standards set by the tile roofing industry allow for different installation methods based on roof slope and climate. The counterbatten system is generally recommended as it provides air flow under the tiles and improved moisture drainage [3]. Testing from Oak Ridge National Laboratory documents additional benefits as the counter-batten system significantly reduces the home's cooling load [4].

This report presents a side by side comparison of polycrystalline silicon (poly-Si) tiles mounted directly to the deck versus those elevated on counter-battens. Builders use direct-deck mounting of concrete tiles as a means to cut bottom-line cost while counter-battens are considered the best practice and can improve home energy efficiency. As neither of these mounting techniques is ideal for $\mathrm{PV}$, a baseline comparison is made against a free-standing, rack-mounted poly-Si module from NREL's performance energy rating testbed (PERT). Although Open Energy's 34 watt roofing tile is the PV module used in this study, the results may be applicable to PV roofing tiles by other manufacturers if the products have similar temperature coefficients and are installed using methods described in this study This report proceeds as follows: Methods of design and installation are presented, the data acquisition system (DAS) is documented, a performance comparison is developed for each mounting method, and conclusions are drawn.

\section{DESIGN AND INSTALLATION}

The design of a PV/concrete tile roof system began with constraints provided by available roof space at NREL's outdoor test facility. It was desired to have a test bed that was similar to a typical residential installation in that the roof should face south and have slope somewhere between $3 / 12$ and $7 / 12$. To meet these requirements the shed shown in Fig. 1 was chosen. 


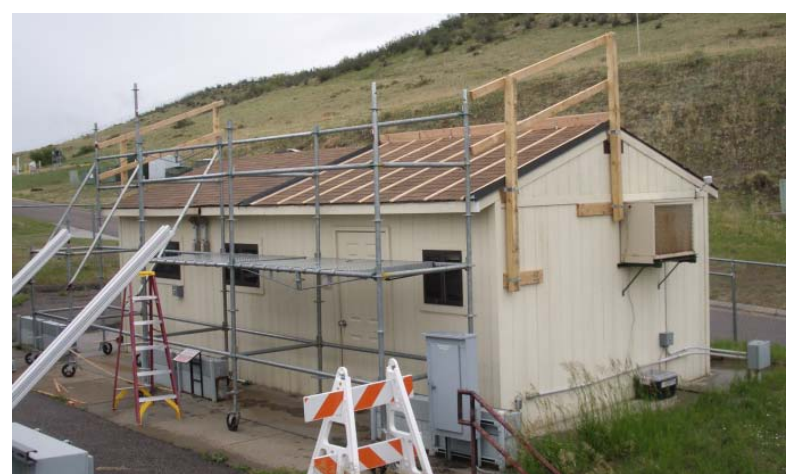

Fig. 1. NREL shed/BIPV test bed

The roof shown in Fig. 1 has a slope of 4/12 and faces due south. The workable area of the BIPV system is approximately 338 " by 102 " and after mounting, the modules will be tilted at roughly 15 degrees. The module pitch is a few degrees less than that of the roof tilt as the bottom of the modules are raised to rest on the top of the modules below them. NREL is located at 39.74 latitude and -105.18 longitude. Although latitude tilt is typically desired for maximizing year round energy production, a reduced tilt is well suited for the summer months in which testing was completed.

Initial plans were to have the two systems side by side, grid tied, and running on independent inverters. Design calculations with the following specifications from the Open Energy modules presented problems with this approach.

$\begin{array}{ll} & 34 \text { W Solar Save Roof Tile } \\ \mathrm{P}_{\max } & \text { 34 Watts } \\ \mathrm{I}_{\mathrm{mp}} & \text { 7.09 Amps } \\ \mathrm{V}_{\mathrm{mp}} & 4.8 \mathrm{Volts} \\ \mathrm{I}_{\mathrm{sc}} & 7.76 \mathrm{Amps} \\ \mathrm{V}_{\mathrm{oc}} & 6.07 \text { Volts }\end{array}$

The roof space on the shed limited the number of tiles per side to 24 while still having a minimal border of concrete tiles. Calculations accounting for high temperatures at NREL indicate that $V_{m p}$ could realistically drop to 3.82 volts. A string of 24 modules in series operating at MPP would only reach 92 volts. As an inverter that can peak power track at such a low voltage was not readily available, plans were changed. The design was modified to have 17 modules in each mounting configuration but connect all 34 modules in series to one grid-tied inverter. At standard test conditions this means the system would output 1156 DC watts at around 7 amps and 163 volts. The PV Powered $1100 E V R$ inverter was chosen as it can peak power track as low as $115 \mathrm{DC}$ volts and its $\mathrm{AC}$ power rating makes it a good fit for this application.

The modules from each side of the roof were run into a junction box as an individual string and then connected together as a single string at a terminal block. This allowed for easy measurement of the voltages from each system while both systems were forced to operate at the same current. Because current is relatively unaffected by temperature changes, this configuration provided a means to compare performance of the two mounting schemes.

Fig. 1 shows the shed roof just after rake metal and $1 \times 2$ counter-battens were installed on the right side. The battens and metal were installed directly on top of existing asphalt shingles. While this is acceptable practice by the concrete tile association, a new home would have an underlayment material or appropriate membrane installed over the decking before battens are installed. The rake metal serves several purposes. It channels water down and off the roof, creates an aesthetic trim, and provides an airflow barrier between the two installation methods. Fig. 2 shows the right side of the shed with the complete counter-batten system in place.

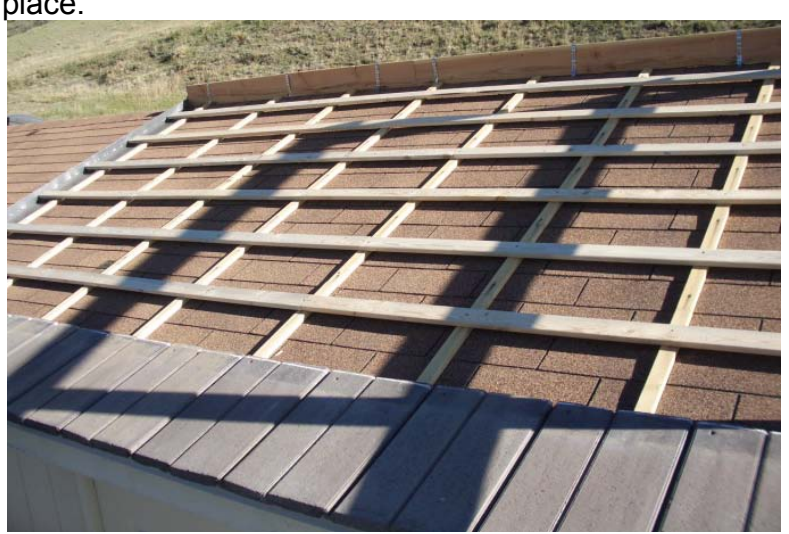

Fig. 2. Counter-batten system/first row of concrete tiles

Fig. 2 also shows the first row of concrete tiles hung on one of the horizontal battens. The counter-battens run from eave to ridge and provide an unobstructed flow path for convective cooling. The horizontal batten at the eave has been covered by $L$ metal to protect it from weather but Fig. 3 illustrates that air can still freely pass underneath between battens and through slots on the bottom of the concrete tiles. A typical installation progresses up the roof with the PV tiles being installed no different than concrete tile, with the exception that leads from each module must be plugged together as the installation progresses.

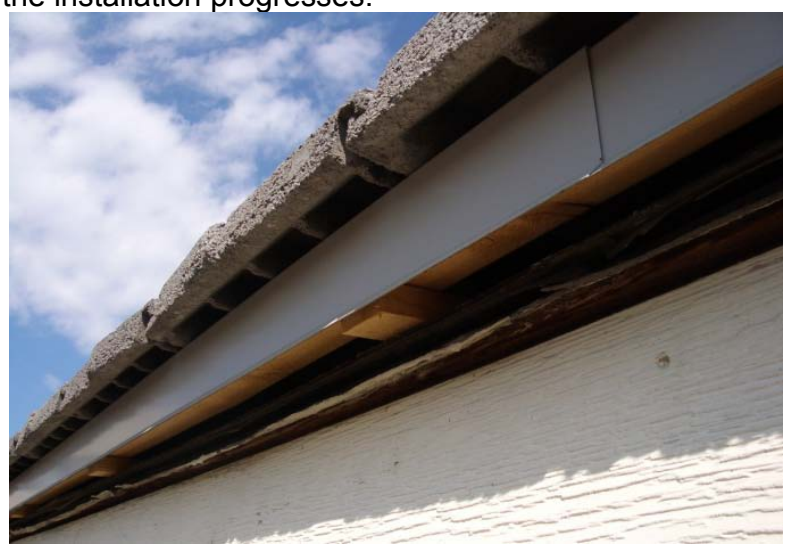

Fig. 3. Air path to the bottom side of the tiles 
Fig. 4 presents a view of modules integrated with concrete tiles. Module leads were connected as each tile is placed while the terminating leads come out at the eave and are maintained in an open circuit condition.

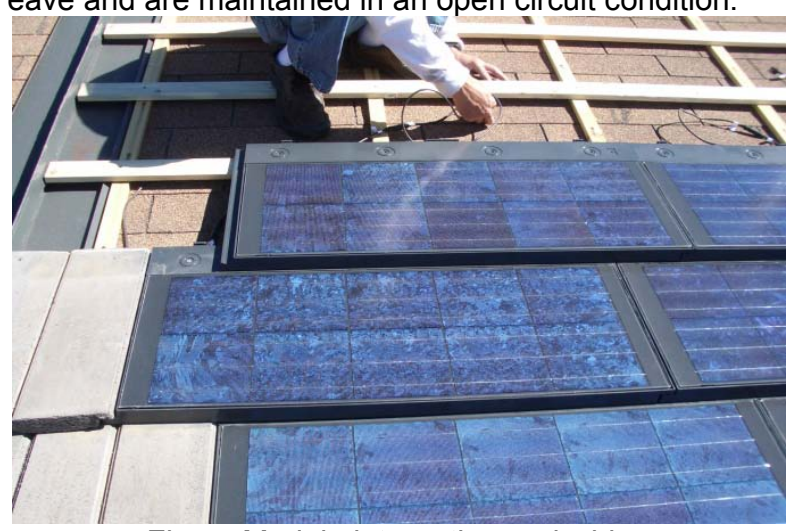

Fig. 4. Module integration and wiring

The completed installation on counter-battens is shown in Fig. 5. A thermocouple has been attached to the back side of two $\mathrm{PV}$ modules, one on the row closest to the eave and one on the full row closest to the ridge.

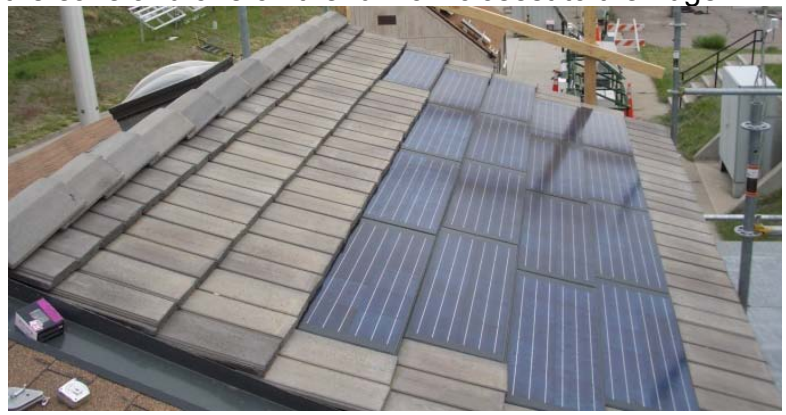

Fig. 5 Complete counter-batten installation

The counter-batten system allows air to enter at the eave and then exhausts at the gaps between the ridge tiles and the field tiles. The field tiles also promote breathing where they overlap and interlock as there are no air tight seals in concrete roofs. Underneath the ridge tiles a breathable vent tape is used to keep water out but let air through, as seen in Fig. 6 .

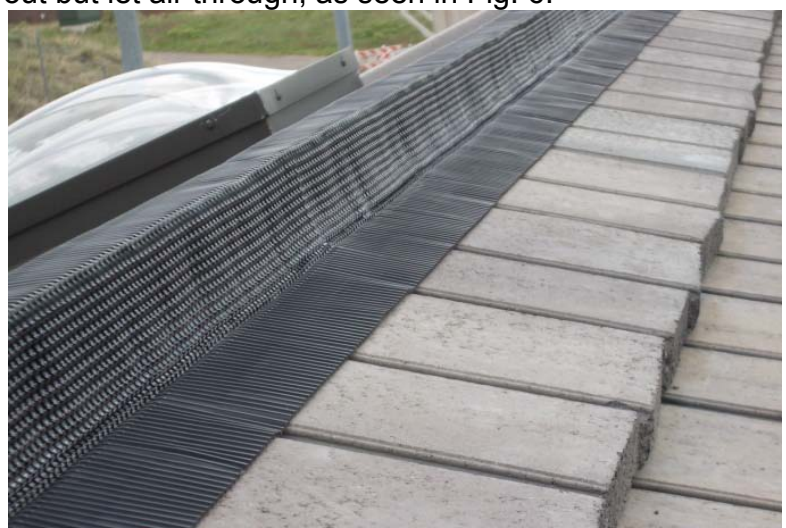

Fig. 6. Vent tape applied under ridge tile
The installation of the direct-mount system on the left side of the roof precedes much the same as the right but without battens. Rather than hanging the tiles on battens, horizontal chalk lines are snapped as a guide for tile installation. A metal riser (L-shaped piece of sheet metal) is placed at the edge of the eave to lift up the bottom end of the first course of tiles. From here the installation proceeds exactly as before, integrating PV wiring and 2 thermocouples along the way. Ridge tape is applied at the top but this time the tape is solid and allows no breathing. Fig. 7 displays the completed side by side system.

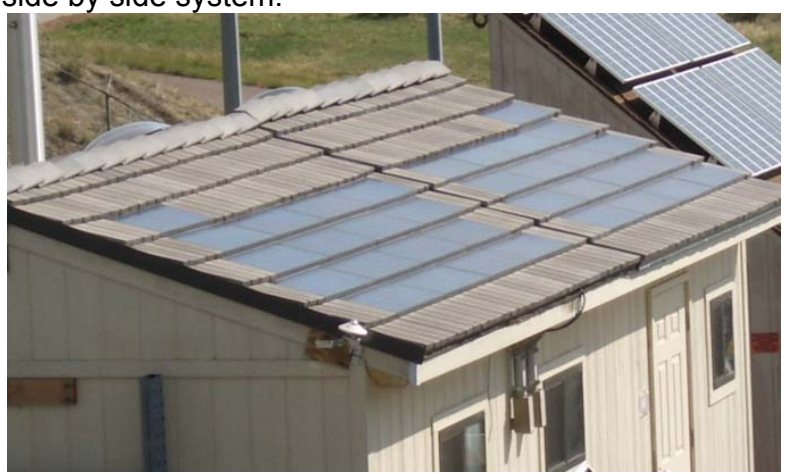

Fig. 7. Completed side by side BIPV system

\section{DATA ACQUISITION SYSTEM}

A Campbell Scientific CR10X data logger in conjunction with Campbell Scientific AM416 multiplexer was used to read low-voltage signals every 5 seconds and record 15-minute average data. A Daystar DS-50 I$\mathrm{V}$ curve tracer was used to produce an I-V curve for each mounting configuration under field conditions. A Kipp and Zonen model CM11 pyranometer was used to measure plane-of-array (POA) irradiance, as seen mounted in Fig. 7. Ambient temperature was measured using a T-type thermocouple housed in a radiation shield. T-type thermocouples were also used to measure the temperature of the 4 previously mentioned modules, the inverter heat sink, and the data logger. A K-type thermocouple probe was used to monitor the shed's attic temperature. Electrical data was measured using the Ohio Semitronic (O.H.) transducers in Table 1.

Table 1 DAS Transducers

\begin{tabular}{|c|c|c|}
\hline Measurement & Device & Range \\
\hline AC current & O.H. CT8-016B & $0-15 \mathrm{~A}$ \\
\hline AC voltage & O.H. VT-120A & $0-150 \mathrm{~V}$ \\
\hline DC current & O.H. CT7-017B & $0-20 \mathrm{~A}$ \\
\hline DC voltage & O.H. VT7-005B & $0-150 \mathrm{~V}$ \\
\hline
\end{tabular}

All O.H. transducers were converted to low $\mathrm{mV}$ signals connecting $2.49 \mathrm{Kohm},+/-1 \%$, resistors across the measurement terminals. Local wind speed data was measured separately by NREL's Reference Meteorological and Irradiance System (RMIS). Transducers were bench calibrated and then the entire data acquisition system was assembled and calibrated 
as a complete unit using a Keithly 2000 multimeter, an HP3478A multimeter, and a Wavetek model 9100 calibrator. The data set examined for this report runs from $7 / 12 / 08$ through 8/31/08 with the exception of a shut down on July $22^{\text {nd }}$ and loss of grid power from 68:45 AM on August $22^{\text {nd }}$.

\section{PERFORMANCE COMPARISON}

As temperature is the primary driver between performance differences, the analysis begins here. As mentioned previously, two module temperatures were measured on each side of the roof. For the counterbatten installation, the eave module was an average of $2.7^{\circ} \mathrm{C}$ cooler than the module nearest to the ridge. For the direct-deck system, the eave module was only an average of $1{ }^{\circ} \mathrm{C}$ cooler than the module close to the ridge. The larger temperature gradient for the counterbatten system is consistent with the convective flow path under the modules. Cool air enters at the eave and is gradually warmed before exiting at the ridge. All performance comparisons and plots that follow report average temperature by installation method. In this case the eave and ridge module temperatures are averaged for the counter-batten and for the direct-mount systems. Fig. 9 plots the counter-batten system's rise of ambient temperature against the rise above ambient temperature for the direct-mount system. Each point is a 15 minute average and all irradiances greater than zero have been plotted. Fig. 8 confirms that the counter-batten installation method consistently results in lower module temperatures but illustrates that there is significant variation in this temperature difference.

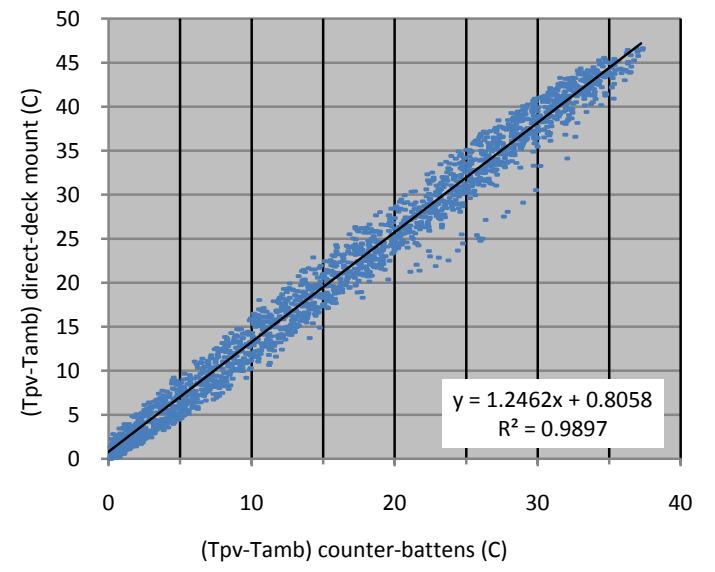

Fig. 8. Module temperature rise above ambient

Factors such as irradiance, time of day, wind speed, and attic temperature, can all interact and lead to variations in module temperature. Fig. 9 provides some insight into these variations over the course of a sunny day. The direct-mount and counter-batten modules are both several degrees below ambient temperature early in the morning, then peak at $43^{\circ} \mathrm{C}$ and $33^{\circ} \mathrm{C}$ above ambient respectively around $12: 30 \mathrm{pm}$, and finally fall back to ambient at about 6:30. This rise and fall of module temperature obviously follows the rise and fall of irradiance but other subtle points can be made from this graph. First, ambient temperature is relatively flat as compared to the swing of the module temperatures. Although changes in ambient temperatures can cause a shift in module temperatures, irradiance is the stronger driver of module temperature.

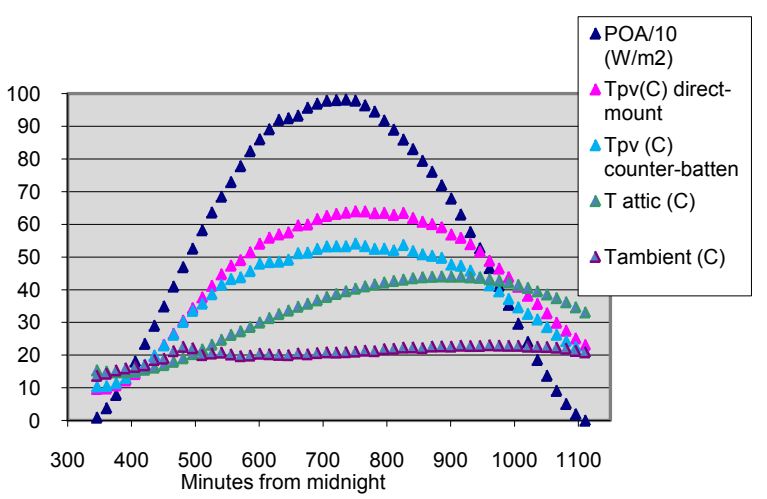

Fig. 9. Irradiance \& Temperatures for Aug $28^{\text {th }}$

Second, over-night cooling of the modules and the attic space effectively nullifies any difference between the systems in the first few hours of the morning. Finally, the two installations do not show diverging temperatures until the attic temperature exceeds ambient. In the afternoon the high attic temperature appears to prolong the temperature difference between systems until the irradiance approaches zero. While this makes thermodynamic sense, it emphasizes the benefit of attic ventilation and suggests an area for further study. The research by Oak Ridge National Laboratory [4] documented that using a counter-batten installation method significantly reduced heat penetration into the attic space and therefore resulted in lower attic temperatures. As attic temperatures have some impact on module temperatures, an ideal study would have isolated attic space for each installation method. This study effectively has no battens on the majority of the roof and therefore the counter-batten modules may have operated at slightly higher temperatures than an isolated installation.

In an effort to better understand how various measured factors relate to module temperature, the data set was analyzed for correlations. Although wind speed and ambient temperature both impact module temperature, the recorded data set provided no clear correlation between these variables and (Tpv-Tamb).

On the other hand weak to modest correlation was found between attic temperature and (Tpv-Tamb), $\left(R^{2}=0.4\right.$ counter-battens, $R^{2}=0.5$ direct-mount). The reduced correlation for the counter-batten system makes intuitive sense as the air gap should provide some isolation from attic conditions. Fig. 10 provides a visual of the relationship between the attic temperature and (Tpv-Tamb) for the counter-batten system. 


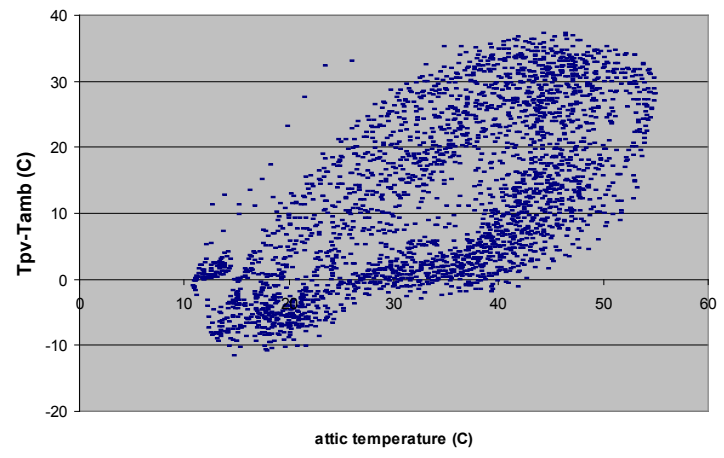

Fig. 10. Attic temp vs. (Tpv-Tamb) counter-battens

As expected there is a strong correlation, $R^{2}=0.8$ for both systems, between POA and (Tpv-Tamb) as seen in Fig. 11. The wide dispersion of data is not surprising as conditions readily occur that cause (Tpv-Tamb) to vary. Fig. 9 already demonstrated how equal irradiances from the morning and afternoon result in different module temperatures. Fig. 9 and 10 both support that attic temperature also impacts module temperature. Finally, many days will have rapidly changing irradiance as clouds come and go. In these events, the data will disperse as the temperature transient is often much slower than the irradiance transient.

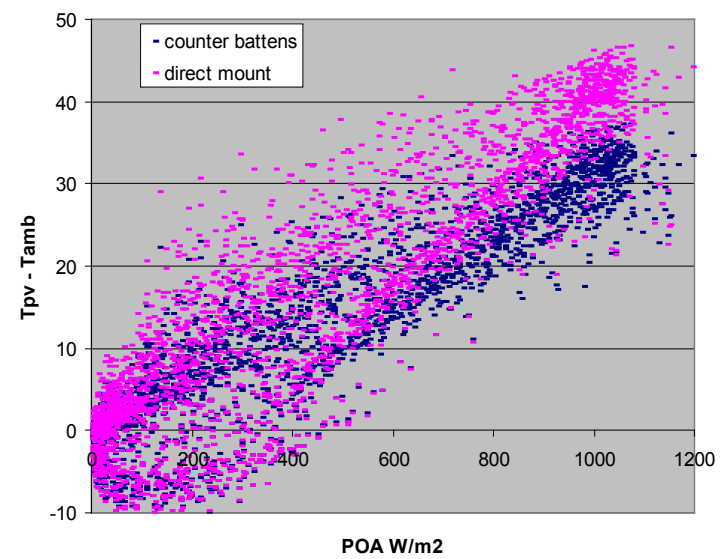

Fig. 11. Temperature rise above ambient vs. POA

Because of the strong correlation between module temperature and POA, it is common practice to calculate the irradiance-weighted temperature and the temperature-rise coefficient given by Equation 1 and 2 .

$$
\begin{aligned}
& T_{\text {weighted }}=\frac{\sum T_{p v} \cdot E}{\sum E} \quad \text { where } E=P O A \\
& T_{\text {rise_coeff }}=\frac{\sum\left(T_{p v}-T_{a m b}\right)}{\sum E}
\end{aligned}
$$

The irradiance-weighted temperature parameters are presented in Table 2 for the entire data set as well as just the month of August. The August calculation was made to facilitate easy comparison to NREL PERT data which is broken into month blocks.
Table 2 Irradiance-weighted temperatures

\begin{tabular}{|l|l|l|}
\hline & August & July12-Aug31 \\
\hline $\mathrm{T}_{\text {weighted(counter-batten) }}$ & $48.16^{\circ} \mathrm{C}$ & $49.34^{\circ} \mathrm{C}$ \\
\hline $\mathrm{T}_{\text {weighted }}$ (direct-mount) & $53.9^{\circ} \mathrm{C}$ & $55.37^{\circ} \mathrm{C}$ \\
\hline $\mathrm{T}_{\text {rise_coeff }}$ (PERT rack) & $21.3^{\circ} \mathrm{C} / \mathrm{kW} / \mathrm{m}^{2}$ & \\
\hline $\mathrm{T}_{\text {rise_coeff(counter-batten) }}$ & $28.7^{\circ} \mathrm{C} / \mathrm{kW} / \mathrm{m}^{2}$ & $27.7^{\circ} \mathrm{C} / \mathrm{kW} / \mathrm{m}^{2}$ \\
\hline $\mathrm{T}_{\text {rise_coeff }}$ (direct-mount) & $37.1^{\circ} \mathrm{C} / \mathrm{kW} / \mathrm{m}^{2}$ & $36.3^{\circ} \mathrm{C} / \mathrm{kW} / \mathrm{m}^{2}$ \\
\hline
\end{tabular}

As expected, rack-mounted modules will operate at the lowest temperatures, followed by the counter-batten system, and then direct-deck mounted modules. In other words, at noon on a sunny day it would be expected that modules on counter-battens would operate roughly $8-9{ }^{\circ} \mathrm{C}$ cooler than with no battens and 7 ${ }^{\circ} \mathrm{C}$ hotter than a rack-mount system.

If the temperature-rise coefficient for August is considered a proxy for INOCT, the temperature differences between counter-batten mounting and rack mounting, and direct mounting and rack mounting were observed to be $6.6^{\circ} \mathrm{C}$ and $5.2^{\circ} \mathrm{C}$ less than expected by PVFORMs prediction for a 1 inch standoff and directmount respectively [2]. This may be a consequence of direct-mounted tiles having their lower edge raised, which permits air flow from the sides. Likewise, the counter-batten installation may have more effective air flow than the one inch standoff height would indicate. Additionally, the temperature-rise coefficients for the roof-mounted tiles may be lower than PVFORM would indicate due to sub-ambient attic temperature seen in the first couple hours of the morning. The thermal model used by PVFORM makes the assumption that surfaces behind the modules (typically the ground or roof) will always be in a range that is bounded by the ambient and module temperatures [5]. Sub-ambient attic temperatures violate this assumption and help keep modules cooler than would be otherwise expected.

Although it is important to quantify each temperature-rise coefficient, it may be appropriate for the consumer, to quantify system differences in terms of power produced. As a precursor to comparing power measurements, it is first necessary to compare baseline measurements for each string. Prior to installation on the shed roof, all modules were tagged and characterized indoors using a SPIRE 240A. By Spire measurements at STC, the modules connected to form the counter-batten string should have a $V_{M P}$ of 81.696 volts while the direct-mount string's $V_{M P}$ should be 81.475 volts. If both strings operate at the lowest $I_{M P}$ of all the modules this would result in a $0.27 \%$ difference in power between the strings. As a secondary check that the strings were well matched in voltage, the outdoor data were filtered for occurrences when the POA was between $920-1150 \mathrm{~W} / \mathrm{m}^{2}$ and module temperatures were within $+/-1.1{ }^{\circ} \mathrm{C}$ of each other. This data resulted in a $\mathrm{V}_{\mathrm{MP}}$ of 66.15 volts for the counter-batten string and 66.1 volts for the direct-mount string, only a $0.07 \%$ difference. With the voltage difference being very small for both of these baselines, it is fair to conclude that 
deviations in power will be the result of thermal conditions resulting from mounting configurations.

The previous thermal results made it clear that $\mathrm{POA}$ is the main variable driving a temperature delta between each string. In conjunction with this information, it is useful to compare average system power for data with POA $>100 \mathrm{~W} / \mathrm{m}^{2}$ against data with $\mathrm{POA}>900 \mathrm{~W} / \mathrm{m}^{2}$. POAs less than $100 \mathrm{~W} / \mathrm{m}^{2}$ were dropped as little to no power is produced below this point and POAs above $900 \mathrm{~W} / \mathrm{m}^{2}$ should show the greatest divergence between the two installations.

The results for these POA ranges are given in Table 3 .

Table 3. Average System Data

\begin{tabular}{|lc|c|c|}
\hline \multicolumn{2}{|c|}{} & \multicolumn{2}{|c|}{ POA range } \\
\hline \multicolumn{2}{|c|}{ Averaged Data } & $>100 \mathrm{~W} / \mathrm{m}^{2}$ & $>900 \mathrm{~W} / \mathrm{m}^{2}$ \\
\hline T_ambient & $\left({ }^{\circ} \mathrm{C}\right)$ & 27.5 & 28.6 \\
\hline POA & $\left(\mathrm{W} / \mathrm{m}^{2}\right)$ & 577.7 & 996.8 \\
\hline Wind & $(\mathrm{m} / \mathrm{s})$ & 2.07 & 2.49 \\
\hline T_pv_battens & $\left({ }^{\circ} \mathrm{C}\right)$ & 44.0 & 59.0 \\
\hline T_pv_direct & $\left({ }^{\circ} \mathrm{C}\right)$ & 48.9 & 67.4 \\
\hline V_mp_battens & $(\mathrm{V})$ & 72.4 & 66.6 \\
\hline V_mp_direct & $(\mathrm{V})$ & 70.7 & 63.5 \\
\hline DC_Watts_batten & $(\mathrm{W})$ & 288.9 & 468.5 \\
\hline DC_Watts_direct & $(\mathrm{W})$ & 279.5 & 446.7 \\
\hline
\end{tabular}

In simple terms the counter-batten installation produced $3.4 \%$ more DC watts for all irradiances greater than 100 $\mathrm{W} / \mathrm{m}^{2}$ and $4.9 \%$ more DC watts in the peak hours when irradiance was above $900 \mathrm{~W} / \mathrm{m}^{2}$.

\section{CONCLUSIONS}

This work has examined the thermal and power characteristics of a BIPV roofing system using two installation techniques, counter-batten and direct-mount. Thermal data showed that in early morning and late evening the two systems operated near the same temperature. On the other hand, in mid-day, as the irradiance increased and the attic temperature exceeded ambient temperature the counter-batten system provided convective cooling to the modules that resulted in temperatures that were as much as $10{ }^{\circ} \mathrm{C}$ lower than the direct-mount system. Irradiance-weighted temperature coefficients were compared for both BIPV installations in comparison to PERT data for a rackmounted poly Si module. Results showed that the temperature-rise coefficient was $7.4^{\circ} \mathrm{C} / \mathrm{kW} / \mathrm{m}^{2}$ higher for the counter-batten modules as compared to the freestanding, rack-mounted module. The direct-mount modules were another $8.4 \mathrm{c} / \mathrm{kW} / \mathrm{m} \quad{ }^{2}$ higher than the counter-batten modules. The temperature-rise coefficients were $5-6{ }^{\circ} \mathrm{C}$ less than expected based on minimum standoff height; perhaps a consequence of tile roofing systems providing better air flow.

As expected the thermal differences translated into a delta in power for each installation method. Overall the counter-batten system produced $3.4 \%$ more DC power than the direct-mount system. When only irradiances above $900 \mathrm{~W} / \mathrm{m}^{2}$ were considered, the counter-batten system produced $4.9 \%$ more DC Watts.

This work provides a clear contrast between installation techniques for a BIPV concrete tile roof but was limited to a side by side system over a single attic space. Future work could benefit by testing installation methods over isolated attic spaces. This could also be combined with an analysis of the reduction in home cooling load that results with use of the counter batten installation method. Accounting for attic temperature might also lead to improved model estimates of PV module temperature.

\section{ACKNOWLEDGEMENTS}

Appreciation is extended to Open Energy Corporation (renamed Applied Solar) and Eagle Roofing for supplying materials and expertise for completing this project. This work was supported by the U.S. Department of Energy under Contract No. DOE-AC3608G028308 with the National Renewable Energy Laboratory.

\section{REFERENCES}

[1] Dunlop Jim, NJATC, Photovoltaic Systems. American Technical Publishers: Illinois, 2007

[2] Menicucci D. F., Fernandez J. P., User's Manual for PVFORM: A Photovoltaic System Simulation Program For Stand-Alone and Grid-Interactive Applications, Sandia Report, 1988

[3] Tile Roofing Institute, Concrete and Clay Roof Tile Installation Manual for Moderate Climate Regions, ICCES ESR-2015P, July 2006

[4] Miller William, Steep-slop Assembly Testing of Clay and Concrete Tile with and without Cool Pigmented Colors, Oak Ridge National Laboratory, 2005

[5] Fuentes Martin, A Simplified Thermal Model for FlatPlate Photovoltaic Arrays, Sandia Report, 1987 


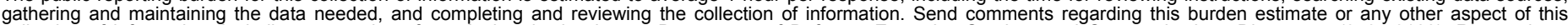

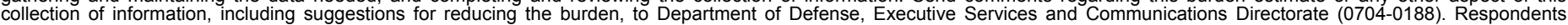

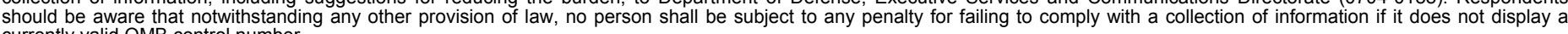

PLEASE DO NOT RETURN YOUR FORM TO THE ABOVE ORGANIZATION.

\section{REPORT DATE (DD-MM-YYYY) June 2009}

\section{TITLE AND SUBTITLE}

Performance Comparison of a BIPV Roofing Tile System in Two Mounting Configurations: Preprint
3. DATES COVERED (From - To) June 7-12, 2009

5a. CONTRACT NUMBER

DE-AC36-08-GO28308

5b. GRANT NUMBER
6. AUTHOR(S)

M.T. Mulller, J. Rodriquez, and B. Marion 5d. PROJECT NUMBER

NREL/CP-520-45948

5e. TASK NUMBER

PVD91410

5f. WORK UNIT NUMBER
7. PERFORMING ORGANIZATION NAME(S) AND ADDRESS(ES)

National Renewable Energy Laboratory

1617 Cole Blvd.

Golden, CO 80401-3393
8. PERFORMING ORGANIZATION REPORT NUMBER NREL/CP-520-45948

9. SPONSORING/MONITORING AGENCY NAME(S) AND ADDRESS(ES)

10. SPONSOR/MONITOR'S ACRONYM(S) NREL

11. SPONSORING/MONITORING AGENCY REPORT NUMBER

12. DISTRIBUTION AVAILABILITY STATEMENT

National Technical Information Service

U.S. Department of Commerce

5285 Port Royal Road

Springfield, VA 22161

\section{SUPPLEMENTARY NOTES}

\section{ABSTRACT (Maximum 200 Words)}

This paper examines the performance of a building-integrated photovoltaic (BIPV) roofing system commonly available to residential markets. In particular, polycrystalline Si PV roofing tiles were integrated with concrete roofing tiles in two mounting configurations being used by roofing contractors. In the first configuration, the tiles were directly mounted to the roof sheeting, allowing little to no airflow under the PV modules. In the second configuration, furring strips were attached to the roof deck to create a counter-batten system to which the roofing and PV tiles mount. This counter-batten system provides an air gap between the roof deck and the PV/concrete, tiles which allows for convective cooling. A complete data acquisition system was applied to both mounting configurations and they were monitored for a summer period in Golden, Colorado. A performance comparison is presented for the systems while both are gauged against free-standing, rack-mounted polycrystalline Si PV modules. As expected, modules mounted directly to the deck operated at higher temperatures and produced less power than those on a counter-batten system, while both systems operated at higher temperatures than rack-mounted modules.

\section{SUBJECT TERMS}

PV; building-integrated photovoltaic (BIPV); roofing tiles; polycrystalline silicon; modules; counter-batten system; temperature; convective cooling; roofing configuration

\begin{tabular}{|c|c|c|c|c|}
\hline \multicolumn{3}{|c|}{ 16. SECURITY CLASSIFICATION OF: } & \multirow{2}{*}{$\begin{array}{l}\text { 17. LIMITATION } \\
\text { OF ABSTRACT } \\
\text { UL }\end{array}$} & \multirow{2}{*}{$\begin{array}{l}\text { 18. } \\
\text { OFMBER PAGES }\end{array}$} \\
\hline $\begin{array}{l}\text { a. REPORT } \\
\text { Unclassified }\end{array}$ & $\begin{array}{l}\text { b. ABSTRACT } \\
\text { Unclassified }\end{array}$ & $\begin{array}{l}\text { c. THIS PAGE } \\
\text { Unclassified }\end{array}$ & & \\
\hline
\end{tabular}

19a. NAME OF RESPONSIBLE PERSON

19b. TELEPHONE NUMBER (Include area code) 